\title{
Reseña de Criado Mainar, Jesús, La escultura romanista en la comarca de la comunidad de Calatayud y su área de influencia. 1589-7639, Calatayud, Centro de Estudios Bilbilitanos, Institución Fer- nando el Católico, Comarca Comunidad de Calatayud, 2013, 413 pp. ISBN: 978- 84-9911-235-0
}

\section{Ma Gabriela Torres Olleta}

GRISO-Universidad de Navarra ESPAÑA

gtorres@alumni.unav.es

[Hipogrifo, (issn: 2328-1308), 3.1, 2015, pp. 295-297]

Recibido: 17-11-2014 / Aceptado: 21-01-2015

DOI: http://dx.doi.org/10.13035/H.2015.03.01.22

Una breve introducción (pp. 9-16) presenta el esquema del trabajo dividido en tres grandes apartados: el primero dedicado al ambiente religioso en la comarca de Calatayud durante los años en los que se aplicaron las consignas tridentidas y que coinciden con la llegada y formación de las corrientes escultóricas romanistas; el segundo centrado en los géneros religiosos y el tercero sobre la evolución del retablo romanista bilbilitano. Continúa con la biografía de los seis artífices más importantes con taller en Calatayud y termina con la bibliografía, apéndice documental, listado de ilustraciones (hay que destacar y agradecer la inclusión de 207 fotografías y numerosas reproducciones de firmas de artistas), índice de artistas e índice de lugares y piezas.

En la primera parte: «El retablo escultórico y los fundamentos del clasicismo» (pp. 28-68) examina las reformas de la Iglesia a partir del Concilio de Trento (15451563) que tuvieron, como es sabido, una importante repercusión en el arte religioso, y que en la Diócesis de Tarazona coincidieron además con el establecimiento de nuevas órdenes como los jesuitas y la revitalización de otras ya asentadas. El retablo mayor de la Catedral de Astorga de Gaspar Becerra (1558-1563) es considerado «verdadero punto de inflexión en el desarrollo del retablo escultórico español» (p. 28) y el autor recorre el camino desde Becerra y su seguidor Juan de Anchieta hasta 
los talleres de Calatayud donde destaca la figura de Pedro Martínez el Viejo figura clave en el «nuevo panorama que cristalizó hacia 1590» (p. 42).

Sigue a continuación un capítulo breve (pp. 49-67) pero importante sobre «Repertorio y sintaxis de los retablos romanistas bilbilitanos» con abundantes ilustraciones paralelas de las obras aragonesas y de la Regola delli cinque ordini d'Arquitettura de Jacopo Barozzi da Vignola, «factor de autoridad entre los retablistas hispanos» (p. 50), así como referencias a los libros de Sebastiano Serlio.

Analiza luego Criado Mainar «Las tipologías del arte sacro: imágenes de devoción, dispositivos eucarísticos y esculturas de aplicación arquitectónica» fundiendo cuestiones de índole formal con las de contenido iconográfico; destacable es el estudio que hace de la devoción de la Virgen del Rosario entre otras como la Asunción de la Virgen, las Vírgenes de la cama, el Niño Jesús, los Cristos crucificados, etc... Relacionados con la Eucaristía aparecen una serie de sagrarios o tabernáculos en los que la escultura es elemento imprescindible, algunos de tan bella factura como el del retablo mayor de la Colegiata de Santa María la Mayor de Calatayud o el de la parroquia de Abanto.

«La evolución del retablo romanista» (pp. 140-259) comienza con el retablo mayor de la parroquia de san Clemente de la Muela de Pedro Martínez, en torno a 1589, y termina con el de san Juan Bautista de Milmarcos obra de Francisco del Condado, Virto, Bastida y Lucas Sánchez de 1637-1639. Entre estas dos obras se analizan numerosos retablos, subrayando las aportaciones novedosas tanto formales cono iconográficas y aportando datos documentales sobre numerosas piezas. En la página 263 comienza el estudio de la vida y obra de los seis escultores con taller en Calatayud más importantes del periodo: Pedro Martínez, «uno de los escultores de más prestigio activos en Aragón al filo de 1600» (p. 266) autor de los retablos de Cascante, de la parroquia de san Clemente de La Muela, del de la Catedral de Santa María de la Huerta de Tarazona etc.; Lope García de Tejada, Jaime Viñola, artífice junto a su yerno Bastida de seis retablos de la colegiata del Sepulcro de Calatayud; Francisco del Condado, Pedro de Jáuregui y Antonio Bastida. En torno a estos obradores aparecen cantidad de escultores ensambladores, pintores etc. que dan idea de la gran actividad de estos talleres y proporcionan al lector gran cantidad de datos útiles, basados en su mayoría en un exhaustivo trabajo de archivo y conocimiento de primera mano de las obras.

Cabría hacer algunas observaciones mínimas sobre la forma de citar la bibliografía (poner en primer lugar el nombre de pila antes de los apellidos dificulta la localización de las entradas). Respecto a la transcripción de los textos documentales Criado Mainar opta por mantener una grafía «antigua» práctica de escasa utilidad, como han mostrado los trabajos sobre edición desarrollados por el GRISO (Grupo de Investigación del Siglo de Oro de la Universidad de Navarra) que propone con buenas razones la modernización gráfica, siempre que no altere la fonética, sistema ampliamente adoptado en el ámbito de la filología hispánica para los textos literarios y cuya aplicación a los textos históricos pienso que puede ser igualmente válida. 
En resumen: estamos ante un excelente trabajo del profesor Criado Mainar, que acierta al situar la obra romanista surgida en Calatayud y su área de influencia, en la panorámica de la retablística peninsular coetánea, al insertar a sus protagonistas en el elenco de maestros españoles y al mostrar un contexto social, religioso y artístico concreto, el bilbilitano, que es a la vez perfectamente extrapolable a otras muchas ciudades y regiones españolas, es además, y no menos importante, un grata invitación a recorrer pueblos, iglesias y conventos en búsqueda de estas obras. 
